\title{
Willow browse blocks for drought protection and for sustainable management of internal parasites
}

\author{
T.N. BARRY ${ }^{1}$, E.L. MCWILLIAM ${ }^{1}$, D.W. PITTA ${ }^{1}$, C.M. DIAZ LIRA ${ }^{1}$, P.D. KEMP ${ }^{1}$, \\ W.E. POMROY ${ }^{1}$, N. LOPEZ-VILLALOBOS ${ }^{1}$, P. GAWITH ${ }^{2}$ and G.B. DOUGLAS ${ }^{3}$ \\ ${ }^{1}$ Massey University, Palmerston North \\ ${ }^{2}$ Waikoukou, RD 4, Masterton \\ ${ }^{3}$ AgResearch, Palmerston North \\ T.N.Barry@massey.ac.nz
}

\begin{abstract}
Browse blocks were developed on wet rush-infested areas of Riverside Farm, near Masterton, by planting 6,000 willow stakes/ha over the winter periods of 2000 , 2001 and 2002. This was followed by light grazing in the first year after planting and then more intensive grazing in later years. After 18 months the areas dried out, due to evapotranspiration from the trees, and a herbage sward developed from volunteer species. The quality of the herbage progressively improved over a 4 year period and the browse blocks now support year-round grazing by sheep. In Experiment 1, ewes that grazed willow browse blocks for 86 days in 2004 (including mating) had higher reproductive performance than ewes that were mated on short, drought affected pasture. However, reproductive performance was lower than that from ewes mated on a sole diet of long herbage similar to that growing in the browse blocks. It was calculated that 15 and $65 \%$ of the metabolisable energy and condensed tannins consumed by ewes grazing browse blocks was provided by willow trees. In Experiment 2, undrenched lambs grazing either control pasture or browse blocks for 98 days in 2005 had lower liveweight and carcass gains than lambs regularly drenched with anthelmintic. Lambs grazing browse blocks consistently had lower dag scores and undrenched lambs grazing on browse blocks had reduced worm burdens of some economically important internal parasites compared with undrenched lambs grazing pasture. It was concluded that the benefits of browse blocks could be due to both direct and indirect effects and that any benefits in internal parasite management may be accompanied by reduced rates of carcass growth. Guidelines are presented for the grazing management of willow browse blocks over a complete 12 month period.
\end{abstract}

Keywords: willow (Salix), fodder tree, drought, internal parasites.

\section{Introduction}

Supplementary willow, comprising leaves and stems $<5$ $\mathrm{mm}$ diameter, contains approx. $10 \mathrm{MJ} / \mathrm{kg}$ dry matter (DM) of metabolisable energy (ME), a total $\mathrm{N}$ of $25 \mathrm{~g} / \mathrm{kg}$ $\mathrm{DM}$ and $45 \mathrm{~g}$ condensed tannin (CT)/kg DM, making it a suitable supplement for grazing livestock (McWilliam et al. 2005a). In a series of three experiments, McWilliam et al. (2005b) showed that supplementation of ewes grazing low quality drought pasture with willow or poplar cuttings during mating increased lambs weaned/100 ewes mated from 102 to 122 . However, mechanically pruning willow/poplar fodder incurred a considerable labour cost, so willow browse blocks were developed, with the objective of livestock doing the harvesting by grazing, so eliminating this labour cost. A first objective was to evaluate browse blocks as an alternative to drought pasture for grazing ewes during mating.

In a review, Min et al. (2003) showed that forages containing CT could be used in some circumstances to reduce burdens of internal parasites in grazing sheep. A second objective was to investigate if grazing on browse blocks could be used as part of a sustainable strategy to reduce parasite problems in grazing lambs, so reducing the requirement for anthelmintic drenches.

\section{Materials and Methods}

\section{Development and management of browse blocks}

Five willow browse blocks totalling 6 ha were planted at 6,000 stems/ha on Massey University's Riverside Farm in the Wairarapa, approx. $10 \mathrm{~km}$ north of Masterton. Planting was done over June/July in 2000, 2001 and 2002. Rush-infested wet areas, that produced no edible forage in the undeveloped state, were selected for development as browse blocks. Generally two and sometimes three hillsides drained into these areas. These areas were mechanically mowed in March to remove the rushes and then blanket sprayed with glyphosate 6 weeks later. Following spraying, some of the areas were then ripped to break up the soil prior to planting. Stakes 70 $\mathrm{cm}$ long were inserted into the ground up to their mid point, at $1.2 \mathrm{~m}$ intervals. The willow clones used were Tangoio and Moutere (one browse block only) (Salix matsudana $\mathrm{x}$ alba).

Soil $\mathrm{pH}$, Olsen P $(\mu \mathrm{g} \mathrm{P} / \mathrm{g})$ and sulphate $(\mu \mathrm{g} \mathrm{S} / \mathrm{g})$ were respectively 5.6, 15 and 10 for the willow browse blocks and 5.5, 30 and 12 for the control pasture areas.

Browse blocks were rotationally grazed with experimental sheep from 25 February to 14 May 2004 in 
Experiment 1 and from 6 December 2004 to 6 April 2005 in Experiment 2. At other times of the year the browse blocks were grazed with non-experimental sheep as needed. Prior to commencing Experiment 2, all of the browse blocks and the control pasture areas were grazed with undrenched lambs and ewes in early lactation, to ensure that all areas were well contaminated with parasite eggs and larvae.

\section{Experiment 1}

Mixed age Romney ewes (initial weight $53 \mathrm{~kg}$ ) grazed simulated drought pasture (two groups) or established willow browse blocks (one group) in 12 weekly breaks, including three cycles of mating ( $\mathrm{n}=167$ ewes/group). For the browse blocks this comprised 10 weeks of primary growth and 2 weeks of regrowth. Drought pastures (long and short) were simulated on shallow soils on Riverside Farm. Short drought pasture was 5-7 $\mathrm{cm}$ tall, low quality and typical of drought conditions. Long drought pasture was $25-30 \mathrm{~cm}$ tall, typical of pasture growing in the browse blocks. Pasture DM mass/ha was measured before and after grazing each break by cutting to ground level, washing and drying at $80^{\circ} \mathrm{C}$ overnight. Tree $\mathrm{DM} /$ ha was similarly measured by cutting representative trees to stump level, before and after grazing, and then cutting these into $2 \mathrm{~cm}$ lengths before drying. Forage allowance was $0.8 \mathrm{~kg} \mathrm{DM} / \mathrm{ewe} /$ day for the short control group and $2.0 \mathrm{~kg} \mathrm{DM} / \mathrm{ewe} /$ day for the long control and browse block groups (including both pasture and edible tree for the latter). Exclusion cages were placed on areas of all pastures and trees at the start of grazing each break and samples taken corresponding to diet selected when the animals left each break. Each group of ewes grazed on separate plots. After mating the three groups were combined and managed as one group until weaning (late spring). Liveweight and body condition score of ewes were measured regularly throughout the experiment up to weaning (late November 2004), whilst reproductive rate was measured at ultrasound pregnancy scanning, lambing, docking and weaning. Further experimental details are described by Pitta et al. $(2005,2006)$.

\section{Experiment 2}

One hundred and twenty weaned Suffolk x Romney lambs were all initially drenched and divided into four groups each of 30. Each group was then allocated to graze either control pasture (undrenched), control pasture regularly drenched, browse block (undrenched) or browse block regularly drenched. Each group grazed a separate area and the lambs were rotated round each area for 14 weeks, using weekly breaks. This comprised 8 weeks of primary growth and 6 weeks of regrowth, for both the browse blocks and the control pastures. The anthelmintic drench used was Erase MPC plus Scanda (Coopers, Schering-Plough, Upper Hutt), a mixture of ivermectin, levamisole and albendazole anthelmintics, which was administered orally at 4 week intervals to the drenched group. Pasture and tree DM mass/ha was measured at the start and end of each break and the mean allowance was $4.9 \mathrm{~kg} \mathrm{DM} / \mathrm{lamb} /$ day; for the browse block groups this included trees and herbage. Exclusion cages were placed over areas of both pastures and trees at the start of grazing each break; diet select samples were taken from the caged areas as the animals left each break

Lambs were weighed, assessed for dag score and rectal sampled for faecal egg counts (FEC) at 2 week intervals. All lambs were slaughtered at the end of the experiment, carcasses were weighed and carcass fat GR depth (mm) measured (an indirect measure of fatness). Carcass weight gain $(\mathrm{CWG})$ was calculated by reference to an initial slaughter group. The abomasum, small intestine and large intestine were collected from 10 sheep in each of the two undrenched groups and used to determine the counts of individual worm species. Further experimental details are given by Diaz Lira (2005).

\section{Statistical Analysis}

All animal data were analysed using individual animals as the statistical unit. For logistical reasons, it was not possible to use areas of land as the statistical unit. Whilst it is realised that this results in confounding between nutritional treatments and areas of land, it is believed not to have altered the conclusions that can be drawn from the present study. Details of the statistical procedures used are given by Pitta et al. (2006).

\section{Results}

Within 18 months of planting the trees, the browse block areas were notably drier. With continued grazing, a herbage sward developed under the trees and the quality of this notably improved with time. This occurred without any introduction of grass or legume seeds and without fertiliser application. The main species present were browntop (Agrostis capillaris), perennial ryegrass (Lolium perenne), Yorkshire fog (Holcus lanatus), lotus (Lotus pedunculatus), white clover (Trifolium repens) and creeping buttercup (Rununculus repens). These changes in herbage composition were apparent by the time Experiment 1 commenced.

\section{Experiment 1}

Short drought pasture had low mass/ha, with a high dead matter content and low legume content (Table 1). ME content (8.2 MJ/kg DM) was low, as would be expected of a drought pasture (Table 2). Consequently, ewes lost weight when grazing short drought pasture 
Table 1 Experiment 1: Pre-grazing and post-grazing mass ( $\mathrm{kg} \mathrm{DM} / \mathrm{ha}$ ) and herbage botanical composition in control (short and long) drought pasture and willow browse blocks grazed during the experiment (mean values with standard errors).

\begin{tabular}{|c|c|c|c|c|}
\hline & \multicolumn{2}{|c|}{$\longrightarrow$ Control $\longrightarrow$} & \multicolumn{2}{|c|}{ Willow fodder block } \\
\hline & Short drought pasture & Long drought pasture & Herbage & Trees \\
\hline $\mathrm{N}^{1}$ & 10 & 8 & 9 & 9 \\
\hline Pre-grazing mass & $1486 \pm 93.1$ & $4256 \pm 306.3$ & $5724 \pm 330.4$ & $814 \pm 79.5$ \\
\hline Post grazing mass & $664 \pm 57.6$ & $2401 \pm 262.2$ & $3605 \pm 304.3$ & $470 \pm 52.6$ \\
\hline \multicolumn{5}{|c|}{ Botanical Composition (\%) } \\
\hline Dead Matter content & $56.9 \pm 6.69$ & $26.9 \pm 3.10$ & $30.6 \pm 3.17$ & \\
\hline Grasses $^{2}$ & $91.4 \pm 1.69$ & $75.6 \pm 4.45$ & $57.8 \pm 3.93$ & \\
\hline Legumes $^{2}$ & $6.2 \pm 1.40$ & $12.7 \pm 2.77$ & $24.0 \pm 4.05$ & \\
\hline Others $^{2}$ & $2.4 \pm 1.28$ & $11.7 \pm 2.80$ & $18.2 \pm 2.97$ & \\
\hline
\end{tabular}

${ }^{1}$ In this and subsequent Tables, $\mathrm{n}$ represents the number of observations per mean value

${ }^{2}$ Percentage of green matter content.

Table 2 Experiment 1: Chemical composition and nutritive value of the pasture and willow diet selected $(\mathrm{g} / \mathrm{kg}$ $\mathrm{DM}$ ) by ewes grazing low quality control drought pastures (short and long) and willow browse blocks (mean values with standard errors).

\begin{tabular}{|c|c|c|c|c|c|}
\hline & \multicolumn{2}{|c|}{$\longrightarrow$ Control } & \multicolumn{2}{|c|}{ — Willow browse block - } & \multirow[b]{2}{*}{ Pooled SEM } \\
\hline & $\begin{array}{c}\text { Short drought } \\
\text { pasture }\end{array}$ & $\begin{array}{l}\text { Long drought } \\
\text { pasture }\end{array}$ & Herbage & Trees & \\
\hline$n$ & 10 & 10 & 9 & 9 & \\
\hline Total $\mathrm{N}^{1}$ & 24.2 & 25.5 & 20.0 & 13.6 & 1.24 \\
\hline $\mathrm{OMD}^{2}$ & 0.57 & 0.65 & 0.60 & 0.67 & 0.014 \\
\hline $\mathrm{ME}^{3}(\mathrm{MJ} / \mathrm{kg} \mathrm{DM})$ & 8.2 & 9.6 & 8.8 & 9.9 & 0.20 \\
\hline $\mathrm{CT}^{4}$ & $1.9 \pm 0.10$ & $2.0 \pm 0.16$ & $3.6 \pm 0.87$ & $38.3 \pm 4.12$ & \\
\hline
\end{tabular}

${ }^{1} \mathrm{~N}$ : Nitrogen; ${ }^{2} \mathrm{OMD}$ : Organic matter digestibility in vitro; ${ }^{3} \mathrm{ME}$ : Metabolisable energy; ${ }^{4} \mathrm{CT}$ : condensed tannin.

Table 3 Experiment 1: Changes in liveweight, body condition score and reproductive rate over the experimental feeding period, when ewes were grazed on control (short and long) drought pastures and willow browse blocks (mean values with standard errors)

\begin{tabular}{|c|c|c|c|c|c|}
\hline & \multirow[b]{2}{*}{ Days } & \multicolumn{2}{|c|}{ Control } & \multirow{2}{*}{$\begin{array}{l}\text { Willow } \\
\text { browse } \\
\text { block }\end{array}$} & \multirow[b]{2}{*}{$\begin{array}{l}\text { Pooled } \\
\text { SEM }\end{array}$} \\
\hline & & $\begin{array}{l}\text { Short drought } \\
\text { pasture }\end{array}$ & $\begin{array}{l}\text { Long drought } \\
\text { pasture }\end{array}$ & & \\
\hline \multicolumn{6}{|l|}{$\begin{array}{l}\text { Liveweight change } \\
\text { (g/day) }\end{array}$} \\
\hline Primary growth + regrowth & 86 & $-17.0^{c} \pm 3.34$ & $54.4^{\mathrm{a}} \pm 3.33$ & $-5.0^{b} \pm 3.31$ & 3.33 \\
\hline Primary growth only & 77 & $-43.1^{c} \pm 3.90$ & $86.8^{a} \pm 3.92$ & $2.3^{b} \pm 3.89$ & 3.90 \\
\hline Body condition score (units) & 86 & $-0.93^{c} \pm 0.033$ & $-0.66^{a} \pm 0.032$ & $-0.77^{b} \pm 0.032$ & 0.032 \\
\hline \multicolumn{6}{|l|}{$\begin{array}{l}\text { Reproductive rate } \\
\text { (lambs/100 ewes mated) }\end{array}$} \\
\hline Scanning & & $135^{c}$ & $183^{a}$ & $147^{\mathrm{b}}$ & 4.81 \\
\hline Lambing & & $116^{c}$ & $157^{a}$ & $134^{b}$ & 4.99 \\
\hline Weaning & & $90^{\mathrm{b}}$ & $113^{a}$ & $89^{b}$ & 5.80 \\
\hline
\end{tabular}

during mating and their reproductive rate was low (Table 3). Long drought pasture, similar to herbage growing in the browse blocks, was of higher mass/ha and legume content (Table 1) and had a higher ME content $(9.6 \mathrm{MJ} /$ kg DM; Table 2). Ewes gained weight when grazing long drought pasture during mating and their reproductive rate was higher than that of ewes grazing short drought pasture during mating $(\mathrm{P}<0.05$; Table 3$)$. Herbage growing in the browse blocks was of slightly higher pasture mass than long drought pasture, but had a similar dead matter content and a higher legume content. ME content was lower at $8.8 \mathrm{MJ} / \mathrm{kg} \mathrm{DM}$. The component of the trees that was eaten contained 9.9 MJ ME/kg DM and a medium CT concentration of $38 \mathrm{~g} / \mathrm{kg}$ DM. Both 
liveweight change and reproductive rate of ewes grazing browse blocks during mating was between that of ewes mated on long drought pasture and short drought pasture $(\mathrm{P}<0.05)$, with liveweight change being close to maintenance (Table 3 ).

\section{Experiment 2}

Herbage and trees that were offered to drenched and undrenched lambs were of similar mass and botanical composition, for the groups grazing both control pasture and willow fodder blocks (Table 4). Pasture mass in the browse blocks was slightly higher than that of control pasture for primary growth but similar for secondary growth. There were no differences in dead matter content and legume content for primary growth, but with secondary growth dead matter content was less and legume content greater for browse block herbage than for control pasture herbage. In contrast to herbage, tree mass/ha was greater for secondary growth than for primary growth.

Organic matter digestibility and ME concentration were similar for browse block pasture and control pasture, at approx. 0.65 and $9.6 \mathrm{MJ} / \mathrm{kg}$ DM. Values were higher for tree diet selected, at approx. 0.70 and $10.5 \mathrm{MJ} / \mathrm{kg}$ DM. Tree diet selected contained lower levels of total $\mathrm{N}$ than pasture, but much higher concentrations of CT (42 $\mathrm{g} / \mathrm{kg}$ DM). Pastures contained very low concentrations of $\mathrm{CT}$, which was consistently higher for browse blocks herbage than for control pasture.

Liveweight gain (Table 6) was greater for drenched than for undrenched lambs $(\mathrm{P}<0.05)$ and was greater for lambs grazing willow browse blocks than control pasture $(\mathrm{P}<0.05)$. Carcass weight gain was also greater for drenched than for undrenched lambs $(\mathrm{P}<0.01)$, but was similar for lambs grazing browse blocks or control pasture. When adjusted to equal carcass weight, carcass GR was lower for drenched animals grazing willow browse blocks than for similar animals grazing pasture $(\mathrm{P}<0.05)$.

Faecal egg counts (FEC) (not shown) were maintained at low levels in the regularly drenched lambs (0-400 epg). FEC progressively increased with time in all three undrenched groups, reaching mean values of $800-1400$ epg by the end of the experiment. Dag score (Table 6) progressively increased with time in all groups; by the end of the experiment dag score was less for regularly drenched than for undrenched lambs $(\mathrm{P}<0.01)$ and was lower for lambs grazing willow browse blocks than control pastures $(\mathrm{P}<0.01)$.

The parasites established in the greatest numbers
$0 \infty$

$\infty$

$0+1+1$

吉 ญे

(1)

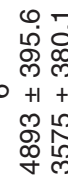

$85 \sqrt{5}$

in

$+1+1+1$

$\infty \omega \infty$

은ํํㄴำ

$N$

œ

$0+1+1$

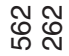

$\infty$

$0+1+1$

ㅇํㅇำ

त्र

$+1+1$

1

๙ேㅇำ
ผึ

ํㅠㅇㅛ ભ

ㅇ.

ธ่ ชั

L $+1+1$

눈

m

จิ ซึ

政+

No

ำ

लेळ लं $+1+1+1$ $\circ \infty 0$ ๓

$\nabla \sigma$

๗்

ए) $+1+1$

مِ

N

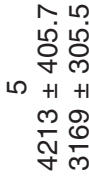

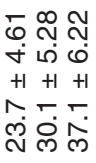

욱소

ठํํㅇ

ণ্লিঙ

$\infty+1+1$

-+1
$++1+1$

- $\infty \omega$

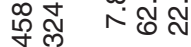

ตุ.

กิ่

$0+1+1$

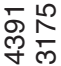

దิ $\infty$

लं

$+1+1+$

तब

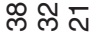

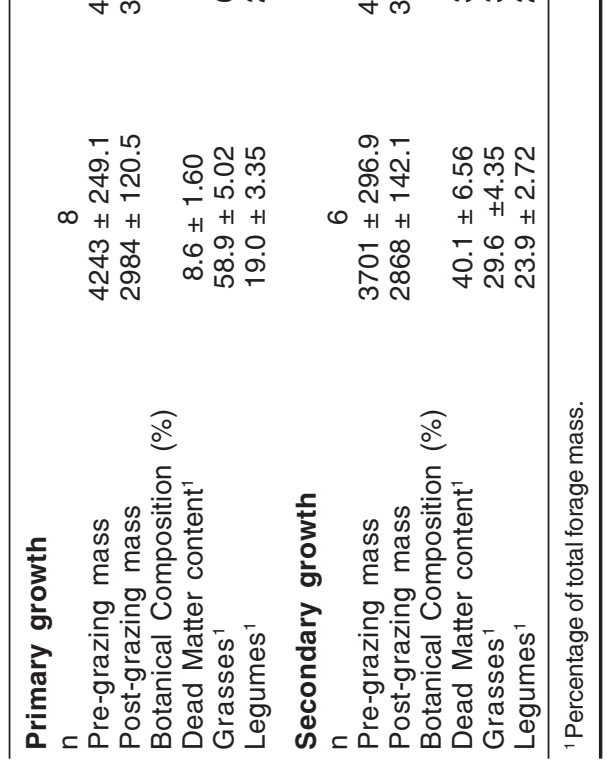


Table 5 Experiment 2: Chemical composition, nutritive value and condensed tannin concentration of pasture and willow diet selected ( $\mathrm{g} / \mathrm{kg} \mathrm{DM})$ by drenched and undrenched lambs grazing control pasture and willow browse blocks (mean values with standard errors)

\begin{tabular}{|c|c|c|c|c|c|c|c|}
\hline & \multicolumn{2}{|c|}{ Control pasture } & \multicolumn{4}{|c|}{ _ Willow browse blocks } & \multirow{3}{*}{$\begin{array}{c}\text { Pooled } \\
\text { SEM }\end{array}$} \\
\hline & \multirow[t]{2}{*}{ Drenched } & \multirow[t]{2}{*}{ Undrenched } & \multicolumn{2}{|c|}{ Drenched } & \multicolumn{2}{|c|}{ Undrenched } & \\
\hline & & & Herbage & Trees & Herbage & Trees & \\
\hline $\mathrm{n}$ & 7 & 7 & 7 & 7 & 7 & 7 & \\
\hline Total $\mathrm{N}^{1}$ & 28.1 & 27.7 & 24.7 & 16.4 & 24.3 & 17.2 & 0.99 \\
\hline $\mathrm{OMD}^{2}$ & 0.66 & 0.65 & 0.64 & 0.70 & 0.65 & 0.71 & 0.013 \\
\hline $\mathrm{ME}(\mathrm{MJ} / \mathrm{kg} \mathrm{DM})^{3}$ & 9.8 & 9.6 & 9.4 & 10.4 & 9.6 & 10.6 & 0.19 \\
\hline Total $\mathrm{CT}^{4}$ & $6.4 \pm 1.24$ & $6.0 \pm 2.25$ & $12.6 \pm 3.58$ & $41.6 \pm 10.41$ & $14.7 \pm 0.89$ & $42.2 \pm 9.36$ & \\
\hline $\begin{array}{l}{ }^{1} \mathrm{~N} \text { : Nitrogen } \\
{ }^{2} \mathrm{OMD} \text { : Organic mat } \\
{ }^{3} \mathrm{ME} \text { : Metabolisable } \\
{ }^{4} \mathrm{CT} \text { : Condensed tar }\end{array}$ & $\begin{array}{l}\text { atter digestibility } \\
\text { e energy } \\
\text { Innins; } n=3 \text { sar }\end{array}$ & vitro. & 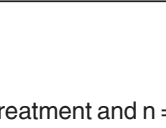 & 0 & c & tment. & \\
\hline
\end{tabular}

Table 6 Experiment 2: Liveweight and carcass gains of drenched and undrenched lambs grazing control pastures and willow browse blocks (mean values and pooled standard errors)

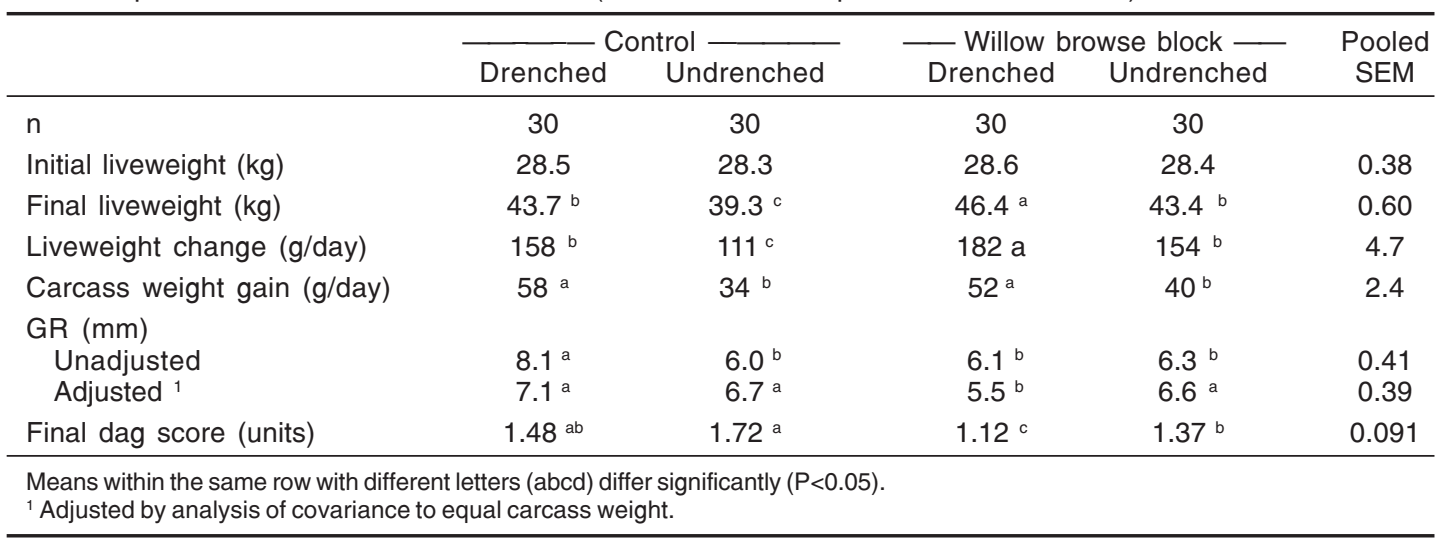

Table 7 Experiment 2: Square root transformed worm counts in undrenched groups grazing control pasture and willow browse blocks (mean values and pooled standard errors)

\begin{tabular}{lccc}
\hline & Control Pasture & Willow browse block & Pooled SEM \\
\hline $\mathrm{n}$ & 10 & 10 & \\
Abomasum & & & $16.79^{\mathrm{a}}$ \\
Haemonchus contortus & $6.68^{\mathrm{b}}$ & $87.33^{\mathrm{a}}$ & 1.174 \\
Teladorsagia circumcincta & $85.52^{\mathrm{a}}$ & $23.10^{\mathrm{a}}$ & 1.077 \\
Teladorsagia trifurcate & $24.23^{\mathrm{a}}$ & $14.02^{\mathrm{a}}$ & 0.676 \\
Trichostrongylus axei & $14.87^{\mathrm{a}}$ & & \\
Small intestine & & & $16.52^{\mathrm{b}}$ \\
Nematodirus spathiger & $53.77^{\mathrm{a}}$ & $6.41^{\mathrm{a}}$ & 1.039 \\
Nematodirus filicollis & $9.87^{\mathrm{a}}$ & $24.68^{\mathrm{b}}$ & 3.119 \\
Trichostrongylus vitrinus & $62.97^{\mathrm{a}}$ & $16.99^{\mathrm{b}}$ & 1.498 \\
Trichostrongylus colubriformis & $31.22^{\mathrm{a}}$ & $17.06^{\mathrm{a}}$ & 1.457 \\
Cooperia curticei & $20.71^{\mathrm{a}}$ & $1.98^{\mathrm{a}}$ & 0.065 \\
Cooperia oncophora & $2.58^{\mathrm{a}}$ & & \\
\hline
\end{tabular}

Means within the same row with different letters ${ }^{\left({ }^{a b c}\right)}$ differ significantly $(\mathrm{P}<0.05)$. 
in undrenched lambs grazing control pasture were Teladorsagia circumcinta, Nematodirus spathiger, Trichostrongylus vitrinus and Trichostrongylus colubriformis followed by Trichostrongyolus axei (Table 7). Undrenched willow browse block fed lambs had significantly lower $(\mathrm{P}<0.05)$ Nematodirus spathiger, Trichostrongylus vitrinus and Trichostrongylus colubriformis worm burdens at slaughter than undrenched lambs grazing control pasture, but greater burdens of Haemonchus contortus $(\mathrm{P}<0.05$; Table 7).

Numbers of Trichostrongylus axei, Nematodirus filicollis, Cooperia curticei, Chabertia ovina, Oesophagostomun venulosum and Trichuris spp. showed no statistical differences between treatments $(\mathrm{P}>0.05$; Table 7).

\section{Discussion}

These studies have shown that willow browse blocks can be used successfully during droughts, to prevent a decline in reproductive rate which would otherwise have occurred when mating ewes on short drought pasture. They have also shown that grazing undrenched weaned lambs in willow browse blocks reduced burdens of some of the most important internal parasites, compared with grazing undrenched lambs on conventional pastures. Grazing browse blocks was not as effective as anthelmintic drenching for control of internal parasites; however, use of browse blocks could lead to a reduction in anthelmintic use and give a more sustainable grazing system.

Reasons for these effects could be due to direct effects of grazing young willow trees, such as their taller morphology compared with normal pasture and the nutritional effects of secondary compounds such as CT, as well as some indirect effects. The latter occurred as a result of drying out of these areas following tree planting, allowing volunteer herbage to establish. Compared with control pastures growing nearby, the most notable effects of browse block herbage was the reduced dead matter content, increased legume content and increased CT concentration. Most of the latter was due to volunteer Lotus pedunculatus, which appeared to suit the long grazing intervals needed for a tree/pasture system (7-8 weeks). The CT in lotus herbage accounted for approx. $35 \%$ of the CT eaten by sheep grazing the browse blocks.

Relative to mating on short drought pasture, Experiment 1 showed that mating on willow browse blocks could be used to increase reproductive rate by a similar extent to direct supplementation with willow cuttings, as summarised by McWilliam et al. (2005b). Therefore, grazing on established willow browse blocks could be used to reduce labour costs associated with cutting willow for supplementation. Whilst willow browse blocks can also be grazed by ewes during mating in non-drought years, the results of Experiment 1 suggest that this will not be as effective as mating on a diet of herbage only. From the pre- and post-grazing cuts made in Experiment 1, it has been calculated that trees provided approx. 15 and $65 \%$ of the intakes of ME and CT of the ewes grazing willow browse blocks (Pitta et al. 2006). Prior to development, the rushes in these areas were so dense that the content of pasture plants was negligible.

One of the most consistent findings in Experiment 2 was the lower dag score of lambs grazing willow browse blocks, for both drenched and undrenched lambs (Diaz Lira 2005). This should aid in the control of fly strike. When looking at production aspects, one of the most relevant comparisons is between regularly drenched control lambs grazing pasture (the conventional farming system) and undrenched lambs grazing willow browse blocks, which were evaluated for possible biological parasite management. Both groups had similar liveweight gain, but carcass weight was reduced for the undrenched lambs grazing browse blocks, suggesting that biological management of internal parasites using browse blocks is likely to incur a penalty of reduced carcass gain. For drenched lambs, grazing on willow browse blocks was associated with reduced carcass fatness, but this was not evident for undrenched lambs.

From the four experiments conducted to date at Riverside farm on grazing willow browse blocks, including the two reported in this paper, it has been possible to devise the following management guidelines for grazing willow browse blocks with sheep on a year round basis.

- Selected sites should have zero or very low productivity in the undeveloped state. The five sites were all wet rush-infested areas, with two and sometimes three hillsides draining into them.

- Cut the rushes with a tractor mounted mower about February. Blanket spray with Roundup (i.e. glyphosate) in late May (do not use herbicide with residual soil activity). Then rip and plant during June, using stakes $0.7 \mathrm{~m}$ long. Plant stakes to $0.35 \mathrm{~m}$ depth. Tangoio or Moutere have been planted at 6,000 stems/ ha but lower densities could probably be used. Close the area from livestock, to allow the trees to grow and the herbage to regenerate. Herbage can then be grazed in the first winter. Trees need to be kept under browsing height, but should only be browsed once or twice in their second growing season.

- Exclude all livestock and close up in early October to protect developing tree leaf buds.

- Browse the trees in well established blocks in December, February and March/April, allowing 
about 8 weeks between grazing. Each browse block had been grazed for 7-10 days, in this rotation.

- Graze hard with ewes in mid May, to eat down the tree stems and to remove stemmy pasture. Mechanical topping may be needed to reduce tree height.

- Graze lightly over winter and set stock over lambing (September-early October).

The browse blocks are now being grazed with sheep only. At Riverside Farm, use of cattle to clean-up in May proved impractical, due to pugging and some willow stem breakage.

One of the biggest problems encountered with browse blocks is control of the volunteer grasses growing in them, particularly in spring. The above system of three grazings of the browse blocks at 8 week intervals during the growing season has been devised to keep the herbage under control, and hence of reasonable nutritive value, whilst also allowing the trees to regenerate. The browse blocks at Riverside Farm have now been grazed for 4 years. The number of years the trees will last under this grazing management system is unknown and will be determined in future work.

Collectively, the work has shown that planting wet rush-infested swampy areas with willow stakes can be used to dry these areas such that they can be used as a feed resource by grazing sheep. They can be used as a feed bank for mating ewes during droughts or for the growth of weaned lambs with reduced anthelmintic input.

\section{ACKNOWLEDGEMENTS}

Financial support from MAF Sustainable Farming Fund, Meat \& Wool New Zealand, Massey University and the New Zealand Ministry of Foreign Affairs is gratefully acknowledged.

\section{REFERENCES}

Diaz Lira, C.M. 2005. Willow fodder blocks for growth and sustainable management of internal parasites in grazing lambs. MVSc Thesis. Massey University. Palmerston North.

McWilliam, E.L.; Barry, T.N.; Lopez-Villalobos, N. 2005a. Organic matter digestibility of poplar (Populus) and willow (Salix) forage trees and its in vitro prediction. Journal of the Science of Food and Agriculture 85: 1098-1104.

McWilliam, E.L.; Barry, T.N.; Lopez-Villalobos, N.; Cameron, P.N.; Kemp, P.D. 2005b. Effects of willow (Salix) supplementation for 31 and 63 days on the reproductive performance of ewes grazing low quality drought pasture during mating. Animal Feed Science and Technology 119: 87-106.

Min, B.R.; Barry, T.N.; Attwood, T.G.; McNabb, W.C. 2003. The effect of condensed tannins on the nutrition and health of ruminants fed fresh temperate forages; a review. Animal Feed Science and Technology 106: 319.

Pitta, D.W.; Barry, T.N.; Lopez-Villalobos, N.; Kemp, P.D. 2005. Effects on ewe reproduction of grazing willow fodder blocks during drought. Animal Feed Science and Technology 120: 217-234.

Pitta, D.W.; Barry, T.N.; Lopez-Villalobos, N.; Kemp, P.D. 2006. Willow fodder blocks - an alternative forage to low quality pasture for mating ewes during drought? Animal Feed Science and Technology (In press). 